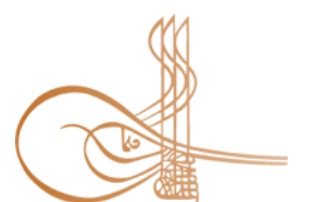

www.turkishstudies.net/social
Turkish Studies - Social Sciences

eISSN: 2667-5617

Research Article / Araștırma Makalesi

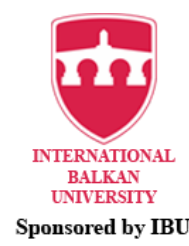

Sponsored by IBU

\title{
Refik Erduran'ın Yemenimin Uçları Tiyatrosunda Toplumcu Gerçekçi Unsurlar
}

\author{
Socialist Realist Elements In Refik Erduran's Theatre Yemenimin Uçları
}

\author{
Uğur Sefa Bilgen* - Ali Pulat**
}

\begin{abstract}
Socialist realism emerged in Russia and spread all over the world in a short time. Important names such as Gorki, Jdanov and Lunaçarski were influential in the process of turning this trend into a literary understanding. In this understanding, collectivity comes to the fore. Socialist realistic writers who diverge from individuality are concerned with social issues. In this theory focused on Marxism, "priority of essence and reality", "revolutionary romanticism and its natural extension positive type" and "partizanship or advocacy" are accepted as the basic principles. İn additin to this, in works related to this understanding historicalism, national consciousness, economic and class conflict and the oppressor and oppressed relationship emerge as supporting factors. Socialist realist theory, Nazim Hikmet effect as soon as possible has been effective in Turkey. Many artists adopt this new view and reflect it on their works. One of these artists is Refik Erduran, one of the important names of the period. Especially known for his theaters, the writer takes the socialist realism of Nazım Hikmet as an example. Refik Erduran's theatre Yemenimin Uçları, the story of Zehra, who is a retired literature teacher depending on her homeland, culture and values is discussed. While Zehra struggles for the unity of her family, which is about to break up as a result of cultural erosion, on the other hand, she calls for a struggle to overthrow the colonial order. As it is known, Refik Erduran depends on socialist realist understanding and includes the elements of this theory in many games. In this context, the purpose of our study is to determine to what extent the elements of socialist realist understanding are included in the game.
\end{abstract}

\section{Structured Abstract: Introduction}

In this study, the socialist realism of theater writer Refik Erduran is discussed. First of all, socialist realism was introduced and the process of being the literary movement of this understanding was discussed. Afterwards, the reflections in Turkish literature are mentioned and the process of influencing Refik Erduran is explained. In this study we created in this context, the answers to the following questions were discussed.

1. What is socialist realism and where did it arise?

2. Who are the artists who are influential in the fact that socialist realism is a literary understanding?

3. What are the main elements addressed in socialist realistic works?

\footnotetext{
* Yüksek Lisans Öğrencisi, Uşak Üniversitesi, Fen-Edebiyat Fakültesi, Türk Dili ve Edebiyat1 Graduate Student, University of Usak, Faculty of Science and Literature, Turkish Language And Literature ORCID 0000-0002-4347-9678

ugurr_bilgen@hotmail.com

*** Doktor Öğretim Üyesi, Uşak Üniversitesi, Fen-Edebiyat Fakültesi, Türk Dili ve Edebiyatı

Asst. Prof., University of Usak, Faculty of Science and Literature, Turkish Language and Literature

ORCID 0000-0002-8923-0782

ali.pulat@usak.edu.tr

Cite as/ Atıf: Bilgen, U.S. \& Pulat, A. (2020). Refik Erduran'ın Yemenimin Uçları tiyatrosunda toplumcu gerçekçi unsurlar. Turkish Studies - Social, 15(5), 2413-2425. https://dx.doi.org/10.47356/TurkishStudies.44099

Received/Geliş: 08 June/Haziran 2020

Accepted/Kabul: 20 August/Ağustos 2020

Checked by plagiarism software

Copyright $\mathbb{C}$ INTAC LTD, Turkey

Published/Yayın: 30 August/Ağustos 2020

CC BY-NC 4.0
} 
4. Who introduced socialist realism to Turkish literature and influenced artists?

5. What are the socialist realistic elements that Refik Erduran deals with in his theaters?

\section{Theoretical Framework}

The socialist realism arising from the realism movement and dealing with social issues has adopted the foundations of the Marxist thought system as a principle and grown up nurturing its philosophy. This movement, which deals with the social dimension of facts, is also known as Socialist Realism, Social Reality, Marxist Realism (Çetişli, 2004: 86). . Reality and future relationship are also important in this understanding, which emphasizes the expression of collectiveness by moving away from individuality. In this context, socialist realist theory does not only tell the reality we are in. It also reports what this reality has turned into (Moran, 2007: 54). Social realism is based on the Karl Marx philosophy and develops with Friedrich Engels. Belinski, Chernishevski, Georg Lukacs, Plehanov, Lunaçarski, Jdanov and especially Maksim Gorki are influential in the emergence of literary understanding and ideological opinion (Akpınar, 2014: 7).

In the vision of socialist realist literature, the purpose of art is to serve people. In this literature, which fundamentally determines the principle of art for society, artists reflect Marxist, socialist-based ideologies to works. According to this ideology, the artist is responsible for society. Referring to the problems experienced in economic, social and political fields, writers use the reality of the period in their art and produce solutions to the problems they identify in the socialist line. The ultimate goal of socially realist writers is to dominate the sense of equality and justice in their works and to criticize the system dominated by exploitation and injustice.

In this context, three basic items are included in socialist realist works. "priority of essence and reality", "revolutionary romanticism and its natural extension positive type" and "partizanship or advocacy" (Oktay, 1986: 143). In our study, we examined Refik Erduran's theatre of Yemenımın Ucları in line with these principles. And to what extent we use these guidelines.

\section{Method}

In our study, one of the qualitative research practices, document analysis method was used. This method is the most used method in terms of examining written sources, subject analysis and various classifications. This method is the most suitable method for our study which has the feature of book review. The purpose of using this method is to obtain reliable data and complete the study accordingly. In this context, the relevant literature was scanned and a work review was conducted in line with the results. With this method, the existence of socialist realist elements in the work was determined and examples related to this were explained.

\section{Findings and Discussion}

Data analysis is one of the most frequently used methods in studies on social sciences. In our study, categorical content analysis, one of the qualitative data analysis methods, was used. With the content analysis conducted, Refik Erduran's theater of Yemenımın Ucları was examined and the socialist realistic elements considered in this direction were classified. As a result of content analysis, a total of five different socialist realistic elements were identified. These elements are "priority of essence and reality" , "partisanship or advocacy", "revolutionary romanticism and its natural extension positive type", "historicalism" and "economic and class conflict". The items classified in this context are explained and examples in the work are shown. We see that the examples determined by content analysis are similar and often appear in dialogues. The socialist realist elements encountered in these dialogues reflect the author's view of art.

\section{Conclusion and Suggestion}

Refik Erduran, which is the subject of our work, is a versatile artist. The author, who is known as a theater writer, has written works in many areas. According to Erduran, theatre is a mirror but this mirror should interfere with people's lives. In this context, the writer demonstrates a socialist realistic understanding. The theatre "Yemenimin Uçları" of Refik Erduran depends on this understanding. In this theatre, the story of a retired literature teacher is told.

Three items come to the fore in the works reflecting the socialist realist understanding: "priority of essence and reality", "revolutionary romanticism and its natural extension positive type" and "partizanship or advocacy". In this work of Erduran we examine, these elements, which are known as the basic principles of

Turkish Studies - Social, 15(5) 
socialist realist understanding, are taken as basis. In addition, supporting elements such as "historicalism" and "economic and class conflict" which are frequently used in works created with a socialist realistic approach, were also considered in this study.

In this his work, Refik Erduran adhered to the principles of "priority of essence and reality" and "partisanship or advocacy" that form the basis of the works based on socialist realist understanding. Refik Erduran emphasizes that he wants to give a message based on socialism in this work. In addition, he defends the right of the worker and laborer to realize her dream of revolution. Reflecting these principles in his work, the author has applied the principle of "revolutionary romanticism and natural extension positive type" to a limited extent. Because the positive hero he created Zehra cannot be succeed despite having enough size. In addition, the writer handled elements such as "historicism", "economic and class conflict" that support the basic principles of socialist realist understanding. Creating an intellectual hero with a history consciousness, the writer establishes the relationship between history and reality in relation to periods. In addition, Refik Erduran emphasizes that inequality has occurred as a result of economic conflict and class conflict. Therefore, it reflects the "worker-boss" relationship of "oppressed-oppressed", "peasant-urban".

Keywords: Turkish Literature, Socialist Realism, Revolutionary Romanticism, Partizanship, Theatre.

Öz: Toplumcu gerçekçilik Rusya'da ortaya çıkmış ve kısa sürede tüm dünyaya yayılmıştır. Bu akımın edebi bir anlayışa dönüşmesi sürecinde Gorki, Jdanov ve Lunaçarski gibi önemli isimler etkili olmuştur. Bu anlayışta kolektiflik ön plana çıkar. Bireysellikten uzaklaşan toplumcu gerçekçi yazarlar toplumsal meselelerle ilgilenirler. Marksizm odaklı bu kuramda "özün ve gerçeğin önceliğgi”, “devrimci romantizm ve doğal bir uzantısı olan olumlu tip" ve "yan tutarlık ya da partizanlık" temel esaslar olarak kabul edilmektedir. Bunun yanı sıra bu anlayışa bağlı eserlerde tarihselcilik, milli bilinç, ekonomik ve sınıfsal çatışma, ezen-ezilen ilişkisi destekleyici unsurlar olarak karşımıza çıkmaktadır. Toplumcu Gerçekçi kuram, Nazım Hikmet etkisiyle kısa zamanda Türkiye'de etkili olur. Birçok sanatçı yeni tanıştığı bu görüşü benimser ve eserlerine yansıtır. Bu sanatçılardan biri de dönemin önemli isimlerinden biri olan Refik Erdurandır. Özellikle tiyatrolarıyla tanınan yazar Nazım Hikmet'in toplumcu gerçekçiliğini örnek alır. Refik Erduran'ın Yemenimin Uçları adlı tiyatrosunda vatanına, kültürüne ve değerlerine bağlı emekli edebiyat öğretmeni olan Zehra'nın hikayesi ele alınır. Zehra bir yandan kültür erozyonu sonucu dağılmak üzere olan ailesinin birliği için çabalarken diğer yandan da sömürgeci düzeni yıkmak için mücadele çağrısı yapar. Bilindiği üzere Refik Erduran toplumcu gerçekçi anlayışa bağlıdır ve birçok oyununda bu kuramın unsurlarına yer verir. Bu bağlamda çalışmamızın amacı, oyunda toplumcu gerçekçi anlayışın unsurlarına ne ölçüde yer verildiğini tespit etmektir.

Anahtar Kelimeler: Türk Edebiyatı, Toplumcu Gerçekçilik, Devrimci Romantizm, Partizanlık, Tiyatro

\section{Giriș}

Gerçekçilik akımından doğan ve toplumsal meselelerle ilgilenen toplumcu gerçekçilik, Marksist düşünce sisteminin temellerini ilke edinmiş ve onun felsefesinden beslenerek büyümüştür. Gerçeklerin sosyal boyutu ile ilgilenen bu akım, Sosyalist Gerçekçilik, Sosyal Gerçeklik, Marksist Gerçekçilik adlarıyla da anılmaktadır (Çetişli, 2004: 86). İsmail Tunalı' ya göre toplumcu gerçekçilik, yaşanılan toplumun insanlarına kişilik ve yaşama bilinci aşılamak, iş bölümü yaparak onları sınıf çatışmalarından ve bireyselliğin getirdiği kaygılardan kurtarmaktır. Bireysel hayatı toplumsal hayata, kişiseli evrensele yöneltmek ve insanın kaybettiği birliği yeniden kurmaktır (Tunalı 1976: 187). Bireysellikten uzaklaşarak kolektiflik ifadesini başat yapan bu anlayışta gerçeklik ve gelecek ilişkisi de önemlidir. Bu bağlamda Toplumcu gerçekçi kuramda sadece içinde bulunduğumuz gerçeklik ele alınmaz. Bu gerçeğin nereye evrildiği de belirtilir (Moran, 2007: 54).

Toplumcu gerçekçilik, Karl Marx felsefesine bağlı olarak oluşur ve Friedrich Engels ile gelişir. Edebi anlayış ve ideolojik bir görüş olarak ortaya çıkmasında ise Belinski, Çernişevski, Georg Lukacs, Plehanov, Lunaçarski, Jdanov ve özellikle de Maksim Gorki gibi önemli isimler etkili olur (Akpınar, 2014: 7). Toplumcu gerçekçi edebiyatın resmiyet kazanması ise 1930'lu yıllara rastlar. Rusya'da ortaya çıkan bu edebiyatın ana ilkeleri 1934'te toplanan "Sovyet Yazarlar Birliği” nin 
Birinci Kongresi'nde tanıtılmış ve toplumcu gerçekçilik o dönemde devletin resmi sanat görüşü olarak ilan edilmiştir (Moran, 1999: 79). Bu anlayışın devletin resmi sanat görüşü olarak ilan edilmesinde büyük etkisi olan Gorki, Jdanov ve Lunaçarski toplumcu gerçekçi anlayışın gerçek kurucuları sayılır (Oktay, 1986: 105). 1934'te, Moskova'da toplanan Yazarlar Birligi Kongre'sinde saptanan ve bir yapıtın toplumcu gerçekçi olup olmadığını anlamakta kullanılacak ölçütler diye adlandırılan ilkeler Maksim Gorki tarafindan dile getirilir:

\section{1. "Toplumcu gerçekçilik daha önceki eleştirel gerçeklikten farklı olarak pragmatik bir edebiyattır ve bir tezi vardır. “ \\ 2. "Sosyalist bireysellik ancak kolektif emek içinde gelişebilir." \\ 3. "Yaşam eylemdir ve yaratmakttr. Yeryüzünde yaşayan insanın ulaşmak isteyeceği en son erek yeryüzünde yaşamak mutluluğudur. " \\ 4. "Sosyalist bireyselliğin geliş̧tirilmesi bu edebiyatın ana amacıdır" (Kahraman, 2004: $50)$.}

Toplumcu gerçekçi edebiyat görüşünde sanatın amacı insanlara hizmet etmektir. Toplum için sanat ilkesini temel olarak belirleyen bu edebiyatta sanatçılar Marksist, sosyalist temelli ideolojilerini eserlere yansıtmaktadır ve bu ideolojiye göre sanatçı topluma karşı sorumludur. Ekonomik, sosyal ve siyasal alanda yaşanan problemlere değinen yazarlar sanatlarında dönemin gerçekliğinden faydalanarak saptadıkları problemlere sosyalist çizgide çözümler üretirler. Toplumcu gerçekçi yazarların en büyük amacı eşitlik ve adalet duygusunu eserlerinde hakim kılmak ve sömürünün, adaletsizliğin hakim olduğu sistemi eleştirmektir. Emek kavramını yüceltirler ve bu kavramı eserlerinin temel taşı olarak tanımlarlar. Toplumcu gerçekçi eserlerde emekçiler ve emekçi haklarının yanı sıra savaş, hürriyet, yoksulluk, baskı, gelecek güzel günler, umut, yarına yönelik iyimserlik gibi temalar sıkça kullanılır (Kahraman, 2004: 51). Zamanla yaygınlaşan anlayış Rusya sınırlarını aşarak evrensel bir ideoloji ve edebiyat anlayışı haline gelir. Bazı sanatçılarımızın bu dönemde Rusya'ya gitmesi ve Rusya'da kaldıkları dönemde sosyalizm felsefesinden etkilenerek toplumcu gerçekçiliğe yönelmesi sonucunda bu akım Türkiye'de de kendine yer bulur.

Toplumcu gerçekçi Türk şairleri Nâzım Hikmet aracılığıyla iki önemli şairi örnek alır: Sovyet Vladimir Mayakovski ve Fransız Louis Aragon (Akpınar, 2014: 13). Nâzım Hikmet, 19201930 yılları arasında Rusya'da kaldığı süre zarfinda hem edebi hem de ideolojik anlamda bir aydınlanma yaşar. Nazım Hikmet'in şiir görüşü, biçim ve içerik anlamında o yıllarda yazılan Türkçe şiirden ayrılır. İdeolojik açıdan ise Nazım Hikmet, temel olarak Leninizm ile biçimlenen sosyalizm etkisindedir (Irmak, 2009: 25). Nazım Hikmet, toplumcu gerçekçi anlayışı Türkiye'ye getiren sanatçıdır ve kendisinden sonraki sanatçıları bu noktada etkileyen isimdir. Kendisini işçinin, emekçinin şairi olarak tanımlayan şair, o zümrenin dertlerini, acılarını ve ihtiyaçlarını anlatmanın en büyük sorumluluğu olduğunu dile getirir (Gürsel, 2001: 71). Sovyet Rusya'da iken Vladimir Mayakovski'den çok etkilenen Nazım Hikmet, sadece Sovyet şiirinden ve şairlerinden değil aynı zamanda Sovyet tiyatrosundan da etkilendiğini, hatta toplumcu gerçekçi anlayışı benimsemesinde Sovyet tiyatrosunun ayrı bir yere sahip olduğunu dile getirir. (Nâzım Hikmet, 2012: 123). Nâzım Hikmet'in toplumcu gerçekçi düşünceye sahip olması genel olarak sanata bakışını belirlemiş ve toplum için sanat yapma ideali onun estetik ölçütünü belirleyen temel düşünce olmuştur (Gülmen, 2016: 19). Onun açtığı yolda özellikle şiirde 1940-1960 tarihleri arasında Ercüment Behzat Lav, İlhami Bekir Tez, Attilâ İlhan, Rıfat Ilgaz, Ahmed Arif, A. Kadir, Enver Gökçe, Ömer Faruk Toprak, Niyazi Akıncıoğlu, Cahit Irgat gibi önemli isimler ortaya çıkmıştır (Aydoğdu, 2017: 10).

Toplumcu gerçekçi edebiyatın ilkeleri belirlendikten sonra bazı tartışmaların cereyan etmiştir. Ahmet Oktay’a göre toplumcu gerçekçi anlayışı yansıtan eserlerde 3 öge ön plana çıkar: 1. "Özün ve gerçeğin öncelliği " 2. "Devrimci romantizm ve doğal uzantısı olumlu tip " 3. "Partizanlık ya da yan tutarlık” (Oktay, 1986: 143). 
Ögelerin ilki olan “özün ve gerçeğin öncelliği” ile anlatılmak istenen şey toplumcu gerçekçi anlayışın şekilden çok özün peşinde olmasıyla ilgilidir. Toplumcu gerçekçi eserin özünde bir tez olmalı ve bu tez verilmek istenen mesaj ya da ideoloji ile harmanlanmalıdır. Bu eserlerde sosyalizm odaklı tezler ele alınır. Berna Moran'a göre toplumcu gerçekçilik özde, toplum gerçekliğini anlattığından devrim sürecini de yansıtır ve bu süreçte işçi sınıfının eğitimi gözetilerek yapılır. (Moran, 2004: 53).

İkinci mesele ise "devrimci romantizm ve doğal uzantısı olumlu tip" tir. Toplumcu gerçekçi anlayışla ortaya çıkan devrimci romantizm ögesi romantik ve gerçekçi unsurların bir araya gelmesiyle oluşur. Marksist, sosyalist yapıda hayatın gerçekliğiyle insanlara aşılanacak olan devrim fikrinin heyecan ve coşku unsurundan yoksun olduğu anlaşılır. Dolayısıyla insanların etkilenmesi ve duygularının harekete geçirilmesi için gerçeklikle birleşen heyecan ve coşku, devrimci romantizm ögesini ortaya çıkarır. Ayrıca gerçekleri yansıtmasının yanı sıra gelecekte gerçekleşecek olan devrimin hayalî olması, "hayal" kavramını da "devrimci romantizm" içinde değerlendirmemizi sağlar. (Soğukömeroğulları, 2010: 1313).

Devrimci romantizmde coşku ve gerçeklik ilkelerini bünyesinde barındırarak geleceğe yön verecek olumlu bir tip yaratılır. Toplumcu gerçekçi eserlerin önemli bir parçası olarak karşımıza çıan bu olumlu tip, toplumun yol göstericisi konumundadır. Geleceğe her zaman iyimser bakan bu kahraman insanları iyi bir gelecek ve sınıfsız bir toplum için umutlandırır. Jdanov'a göre eserlerde olumlu tipi temsil eden kahramanlar planlanmış bir geleceğin adamlarıdır (Moran 2007: 92). Politik erdemin mükemmel bir temsilcisi olan bu tip, okurun saygı duyacağı, imreneceği, nefsine hakim, güçlü bir insan modelidir. Halkın zor durumda kaldığı durumlarda sahneye çıkar ve halka liderlik ederek onları zor durumdan kurtarır. Yaratılan olumlu tipin geleceğin bir parçası olması ve sosyalizm idealleri doğrultusunda insanlara güzel geleceğe dair umutlar vermesi gerçekçiliği ve romantizmi bir araya getirir. Böylece ortaya yeni bir kavram olan "devrimci romantizm" çıkmış olur. Jdanov'a göre bu yeni bir romantizmdir ve Sovyet edebiyatı buna karşı çıkmamalıdır. "Devrimci Romantizm" adını verdiği bu akımla Sovyet edebiyatı olumlu kahramanları yaratabilmeli ve geleceğe bakabilmelidir (Moran,2004: 93).

Üçüncüsü ise "partizanlık ya da yan tutarlık" ögesidir. Sanatta partizanlık dönemin koşullarına bağlı olarak ortaya çıkar ve özgürlük kavramından beslenerek büyür. Toplumcu Gerçekçi anlayışın bu ilkesinin ortaya çıkmasında en önemli isim Lenin'dir. Lenin'e göre edebiyatın bir siyasi görüşü olmalı ve yazarlar eserlerinde yanlısı oldukları partinin ideolojisini yansıtmalıdır (Moran, 2004: 72-73). Bu kavramla yazarın işçi sınıfının haklarını savunduğu ve bu idealizmin siyasetteki temsilcisi olan partiden yana tavır sergilediği görülür. Yazar, eserin özünde verdiği mesajla tarafını açıkça belli eder ve ezilenin yanında olduğunu gösterir.

Çalışmamızın konusunu teşkil eden "Yemenimin Uçları" adlı oyunun yazarı Ahmet Refik Erduran, 1928 y1lında İstanbul'da doğdu. Ortaöğrenimini Robert Koleji'nde tamamlayan Erduran, yükseköğrenimini Amerika'da Cornell Üniversitesi'nde tamamladı. Eğitimini tamamladıktan sonra yedek subay olarak Kore Savaşı'na katıldı. Askerliği sonrasında "Çağlayan Yayınevi” ni kurdu. Bir süre filmcilik de yapan yazar Akbaba, Dolmuş gibi mizah dergilerinde sonrasında da Milliyet ve Güneş gazetelerinde (1965-1988) fikra yazarlığı yaptı (Erduran, 1993: 96). "Deli”, "Bir Kilo Namus", "Cengiz Han'ın Bisikleti" adlı oyunlarıyla ünlenen Erduran'ın çok sayıda oyunu resmi ve özel tiyatrolar tarafindan sergilendi. 1954-1979 yılları arasındaki yimi beş yıllık süreçte iki roman, otuz bir oyun, yedi film ve TV senaryosu ve binlerce basın fikrası üretti (Erduran, 1979: 125). Gazete, TV, ve tiyatro oyunu yazarlığı noktasında yerli ve yabancı birçok ödül aldı. Kısa adı ITI (UNESCO) olan Uluslararası Tiyatro Enstitüsü Türkiye Merkezinin 1986 yılından beri başkanlığını üstlenen Erduran, aynı örgütün 1989 'da Helsinki'de yapılan Dünya Kongresi'nde Uluslararası Yazarlar Komitesi Başkanlığı'na seçildi (Erduran, 2005: 4). 
Refik Erduran'ın toplumcu gerçekçi anlayış güdümünde oluşan edebi anlayışı Nazım Hikmet'in etkisiyle gelişir. Nazım Hikmet, onun eksikliğini duyduğu sanatçı hislerinin tamamlanmasında ve sanat görüşünün oluşmasında çok etkili olur (Erduran, 2005: 303). Erduran'a göre tiyatro bir aynadır. Ancak ayna sadece hayatı yansıtmaz, ona ufak dokunuşlar yaparak insanın insanlaşmasına katkıda bulunur (Erduran, 2011: 9).

Yemenimin Uçları oyununda vatanına, kültürüne ve manevi değerlerine bağlı, emekli edebiyat öğretmeni Zehra'nın hikayesi ele alınır. Kocası dolandırıcılık suçundan arandığ 1 için yurt dışına kaçar ve orada zenginleşir. Oğlunu da Türkiye'den koparıp yanına çekmek ister. Babasının rahat yaşamından ve vaatlerinden etkilenen oğul ülkesinden ve tarihinden nefret etmeye başlar. $\mathrm{Bu}$ duruma çok üzülen Zehra psikolojik sorunlar yaşasa da oğluna tarihini, milli duygularını ve özünü hatırlatmaya çalışır. Bir yandan kültür erozyonu sonucu dağılmak üzere olan ailesinin birliği için çabalarken diğer yandan da sömürgeci düzeni yıkmak için mücadele çağrısı yapar.

Erduran'ın toplumcu gerçekçi unsurlar noktasında incelediğimiz bu eserinde Ahmet Oktay'ın toplumcu gerçekçi anlayışın temel esasları olarak ortaya koyduğu "özün ve gerçeğin önceliğì", "devrimci romantizm ve doğal uzantısı olumlu tip" ve "partizanlık ya da yan tutarlık" ögeleri temel alınmıştır. Ayrıca yine toplumcu gerçekçi anlayışla oluşturulan eserlerde sıkça kullanılan "tarihselcilik", "ekonomik ve sınıfsal çatışma" ve "ezen-ezilen ilişkisi" gibi destekleyici unsurlar da dikkate alınmıştır.

\section{Eserde Kullanılan Toplumcu Gerçekçi Unsurlar \\ Özün ve Gerçeğin Önceliği}

Toplumcu gerçekçi eserin özünde bir tez olmalı ve bu tez verilmek istenen mesaj ile desteklenmelidir. Berna Moran'a göre toplumcu gerçekçilik özde, toplum gerçekliğini anlattığından devrim sürecini yansıtmakta ve bu süreçte işçi sınıfının eğitimi gözetilerak yapılmaktadır (Moran, 2004: 53). Bu bağlamda toplumcu gerçekçi anlayışa bağlı eserlerde sosyalizm odaklı bir bakış açısı içeriğe hakimdir. Ahmet Oktay da bu çizgide Marksist bilgi kuramının yansıtmacı yorumda, yazın'ın bilginin özel bir biçimi olduğunu hatırlatarak bu yüzden toplumcu gerçekçi anlayışın öz ve gerçek kavramlarına değer verdiğini söyler. Bu yaklaşımda bir doğru bir de yanlış bilinç söz konusudur. Dolayısıyla yazın eninde sonunda belli bir ideolojiyi yansitır. (Oktay, 1986: 148).

Refik Erduran, Yemenimin Uçları adllı tiyatro eserinde toplumcu gerçekçi anlayışın ögelerinden biri olan "özün ve gerçeğin önceliğì" esasına bağlı kalmış ve okuyucuya vermek istediği tezi ön plana çıkarmıştır. Öz ve gerçek bağlantısı çerçevesinde tezi eserine yerleştiren Erduran, vurgulamak istediği düşünceleri ve ideolojiyi yarattığı bir aydın tip üzerinden okuyucuya aktarmıştır.

Olayların merkezinde yer alan Zehra, aydın bir edebiyat öğretmenidir ve tarihine, değerlerine son derece hakimdir. Kocası ve oğlunun Batı hayranlığıyla mücadele eden Zehra bu noktada psikolojik sorunlar yaşasa da ülkesinin değerlerinden ve tarihinden asla vazgeçmez. Her firsatta Türkleri ve Türk tarihini aşağılayarak Batı'nın sömürgeci düzenine hayranlık besleyen kocası ve oğluna tarihten örneklerle karşıllk verir. Doğu'nun değerlerini savunurken Batı'nın yüzyıllardır sömürgecilik faaliyetleriyle insanları tükettiğini ve halklara zulmettiğini hatırlatır. Bu noktada yazar gerçek mücadelenin kocaya ve oğula karşı olmadığını okuyucuya hissettirir. Aslında Zehra, dünyaların ve sınıfların eşitliği temeline dayanan sosyalizm ideolojisine bağlıdır ve bu ideolojiyi vurgulayarak ezilen insanların mücadelesini savunur. Özellikle Zehra'nın aydın kişiliği üzerinden tarihten somut isimlerle örnekler verilmesi de öz ve gerçek bağlantısını güçlendirir. Yazar burada toplumcu gerçekçi anlayışta sıkça karşılaştığımız tez - antitez yöntemini uygular. Refik Erduran kendi düşüncelerini savunan bir kahramanın yaratırken karşısına da karşı1t olduğu düşüncenin temsilcilerini yerleştirmiştir. Bu hususta eserde birçok örnek görürüz.

Öncelikle Zehra'nın oğlu Efe'nin Türk halkını koyun sürüsüne benzetmesi ve haklarına sahip olamadıkları için sömürülmeyi hak ettiklerini düşünmesi Zehra'yı çok üzer. Zehra bu halkın tarihinin 
başkaldırı örnekleri ve özgürlüğü temsil eden önemli isimlerle dolup taştığını söyledikten sonra Nefi örneğini verir.

"ZEHRA - Pisliklerden böyle kurtuldu Nefi. Başkaldırı uğruna başını vererek. Yani oğlum, Efeciğim, sandığın gibi bizim eskiler koyun sürüsü değil. Akintıya kürek çekenler de vardl" (s. 23).

Toplumcu gerçekçi anlayış ile oluşturulan bir eserde milli bilinç ve yurtseverlik gibi unsurların aydın tiple bütünleşmesi önemlidir. Zehra'nın tarihine hakim olması ve önemli simalardan örnekler vermesi yazarın zihnindeki gerçek aydın modelinin yansımasıdır. Oğlu ve kocası Batı hayranlığı ile Avrupa'ya kaçan Zehra eser boyunca psikolojik dalgalanmalar yaşasa da değerlerinden, vatanseverliğinden, tarih bilincinden ve eşitlikçi tavrından taviz vermez. Ayrıca oğlu, kocası başa olmak üzere benzer sebeplerle ülkeden kaçanlar dışında mecbur kalarak Avrupa'ya göç edenleri ise ayn bir kefeye koyar. Ezilen insanın refah seviyesine ulaşma isteğini haklı bir sebep olarak değerlendirmesi sosyalist bakışıyla doğrudan ilintilidir. Toplumcu gerçekçi anlayışı destekleyen bu unsurlar öz ve gerçeğin önceliği bağlamında yazar tarafindan bilinçli olarak kullanılmıștır.

Eserde karşımıza çıkan bir başka örnekte de Zehra'nın yine hastane odasında kocasının hayali ile eşitlik üzerine tartıştığını görürüz. Oğlu ve eşinin zamanında sırf kadın olduğu için ona harman dalı oynatmadığını hatırlayan Zehra sinirlenir. Eşitlik mücadelesine kadın-erkek eşitliğini vurgulayarak başlayan Zehra eşi Nuh'un "eşitsizlik artık dünyaya hakim" (s. 41) vurgusuna kızarak halkının bu yoldaki çilesini ve bu mücadelede feda ettiklerini hatırlatır.

"NUH - Herkes. Efeler çook gerilerde kaldı. Çağımıza gel çağımıza. Beylere kafa tutan kaç kişi görüyorsun?

ZEHRA - Binlerce kişi! Hem de memleketin gönlü en yüce insanlarl. Kadinıyla, erkeğiyle kelleyi koltuğa alıp bir şeyleri düzeltmeye çalıştılar. Çok şeyi yüzlerine bulaştırdılar. Ama boşvermediler. Kodeslere düşükleri oldu. Gık demediler. Yıllarca çile doldurdular oralarda" (s. 41).

Bu noktadan sonra "kavga" ve "mücadele" kavramları eserde daha sık karşımıza çıkar. Zehra'nın psikolojik gelgitleri arttıkça "kavga" ve "mücadele" ibareleri de bolca tekrarlanır. Sosyalizm temelli düşünce evrilerek komünizm amaçlı bir devrim propagandasına dönüşür. Zehra bu noktada yazarın sözcücüsü konumundadır ve onun ideolojisinin propagandasını yapar. İnsanları sömüren sistemin devam ettiği sürece mücadelenin de devam edeceğini vurgulayarak gelinen noktada bir devrime ihtiyaç duyulduğunu açıkça belirtir. Arka fonda çalan "Karlı Kayın Ormanı" şarkısı eşliğinde Zehra; Nazım Hikmet'in sosyalizm çizgisinde işçilerin haklarını ve bir devrimi savunduğu için ömrünün yarısını kodeste geçirdiğini ancak yine de mücadelesinden vazgeçmediğini hatırlatır.

"NUH - ... Yenildi Nazım. Hayal kurduğu belli oldu.

ZEHRA - Dava hayal üstüne değil. Senin gibilerin namussuzluğu üstüne. Kavga bitmedi, çünkü sizin saltanatınız bitmedi" (s. 43).

Bu örnekle birlikte "özün ve gerçeğin önceliği" ilkesiyle ilgili olarak bir önemli özellik daha görürüz. Bu anlayışı ortaya koyan eserlerde verilmek istenen mesaj gizlenmez. Vurgulanmak istenen ideolojinin maksadı okuyucuya açıkça ifade edilir. Eser boyunca bu durumu destekleyen benzer örneklerle sık sık karşılaşırız.

\section{Devrimci Romantizm ve Doğal Uzantısı Olumlu Tip}

Toplumcu gerçekçi anlayışla ortaya çıkan ve romantik, gerçekçi unsurların bir araya gelmesiyle oluşan devrimci romantizm, "yazarın geleceğe yönelik iyimser inanışı, insan yaşamının daha ileri bir bütünlenmesine yönelik çaba ve bugün ile gelecek arasındaki sürekliliğe olan sanatsal 
bağlanımdır" (Pospelov, 1985: 323). Bu bağlamda Ahmet Oktay da devrimci romantizmin romantik mirasın bir üst aşamasını temsil ettiğini dile getirir (Oktay, 1986; 188). Devrimci romantizmde gelecek güzel günler için birlik ve mücadele vurgusu yapılır. İşçilerin hakları temel alınarak yaratılacak olan eşit bir dünya için devrimin gerekliliği anlatılır.

Marksist sosyalist sanatçılar, devrimci romantizm ögesi ile bütünleşerek devrim ve mutlu gelecek fikrini topluma aşılayacak bir kahraman insan modeli planlar. Bu kahraman devrimci romantizmin uzantısı olan olumlu tiptir. Berna Moran'a göre bu olumlu tip, temsil ettiği politik görüşün iyi bir savunucusu olarak okurun saygısını kazanmalı, şu anki durum ile gelecek arasında bir bağ kurarak sosyalizm odaklı çözüm üretmelidir. Bu tip, nefsine hakim, görevine bağl1, ve son derece güçlüdür. Yolunu kaybeden ve zor durumda olan halka yol gösteren, onlara liderlik eden bir kahramandır. Karşılaştığı türlü güçlükleri aşarak, zor durumdaki insanları düştüğü durumdan kurtarır. Tüm bunları yaparken de kendisi yalnızlaşır ve yalnızlığını kabullenir (Moran, 2004: 61).

Eserde "devrimci romantizm" esasına bağlı kalan yazar, eser boyunca sosyalizm odaklı kavga-mücadele-eşitlik vurgusu yapmakta ve hayallerin gerçeğe ulaşması için devrimin gerekliliğinden bahsetmektedir. Devrimci romantizmin uzantısı olarak karşımıza çıkan "olumlu tip" ise eserde yer almasına rağmen yetenekleri sınırlıdır. Özellikle eserin başkahramanı Zehra ve eserde sadece bir noktada Nişanlı adı ile karşımıza çıkan kahramanın donanımsal olarak olumlu tip örneğini temsil ettiği, eylemsel boyutta ise eksik kaldığ görülmektedir.

Eserin başında olayların merkezinde yer alan Zehra, Enternasyonal Marşı eşliğinde işçileri karıncaya benzetir ve işçilerin hakkını savunurken ölen kızının nişanlısını hatırlatır. Toplumcu gerçekçi anlayış ile ortaya çıkan "devrimci romantizm" çizgisi burada net bir şekilde görülmektedir. Marksist, sosyalist kurama hizmet ederek işçi sınıfının hakları ve özgürlüğü için çaba harcamak bu esası oluşturan temel düşüncedir.

"ZEHRA - .... Onların da bir adl vardı. Karıncaların. Diline dolamıştı delikanlı...

Proleterya!.. Hepimize nutuk çekerdi. Slogan yazardı duvarlara. "İş̧̧i - Köylü El Ele."

"Emekçilerin Öncülüğ̈̈." "Devrimci Gençlik Göreve." Daha neler neler. Yürüyüşlerde kırmizı bayrak sallardı." (s. 6).

Yine Zehra'nın kızı Ece ve Nişanlı adıyla karşımıza çıkan gencin konuşmalarında görürüz ki yapılacak devrimle her şeyin değişeceğine inanan genç bir adam söz konusudur. Devrime inanan ve gelecekten umutlu olan insan devrimci romantizmin bir parçası olarak karşımıza çıkar. Ancak eserdeki rolü sınırlıdır. İlk ve son kez karşımıza çıkan genç fikirsel boyutuyla devrimci romantizmi temsil eder ve güzel geleceğe inanır. Ancak devrim planlarını gerçekleştiremeden bu uğurda canını verir. Bu yüzden de "olumlu tip" açılımına uyduğu söylenemez.

"NIŞANLI - Bayllyorum sana. Ama ...

ECE - Devrime daha çok bayllyyorsun?

NiŞANLI - Birbirinden ayrı şeyler değil ki. Önce toplum doğuracak. Sonra çocuklarımız doğacak, insanca bir dünyada” (s. 6).

Oyunun odak noktasında yer alan Zehra, emekli bir edebiyat öğretmenidir ve toplumcu gerçekçi anlayışın "olumlu tip" tanımına sadece donanımsal olarak uymaktadır. Bir aydın tipi olarak karşımıza çıkarılan Zehra, kuramda bahsedildiği üzere toplumun kurtarıcısı ya da yol göstericisi değildir. Zehra her ne kadar yakın çevresiyle mücadele ediyor gibi görünse de onun asıl savaş1 toplumun düşünce yapısıyladır. Bu noktada teoride "olumlu tip" örneği olan Zehra eylemsel olarak onun gereklerini sağlayamaz. Savunduğu değerlere bağlılığı tartışılmayacak boyutta olsa bile olumlu tipin güçlü insan modeli değildir. Aksine inişleri çıkışları olan kırılgan bir yapıya sahiptir. Bu yüzden etrafındaki insanları doğruya yöneltme mücadelesinde başarılı olamamıştır. 
Kocası dolandırıcılık yaptığı için Avrupa'ya kaçarak zenginleşir. Batı hayranlığıyla ülkesini, değerlerini ve tarihini aşağılamaya başlar. Sonrasında Avrupa ve zenginlik vaatleri ile oğlunu da Türkiye'den uzaklaştırır. Her ikisi de sömürgeci düzeni savunan bireylere dönüşür. Bu noktada, Zehra her ne kadar değerlerine sahip çıksa da oğlunu ve eşini doğruya yönlendiremez. Doğu'nun değerlerine, milli bilince sahip çıkmak, Türk insanını ve tarihini aşağılayanlara firsat vermemek noktasında okuyucuyu etkiler ancak eylem noktasında başarılı olamaz. Düşünsel alt yapısıyla Batı'nın kapitalist, sömürgeci düzenini eleştirir.

\begin{abstract}
"Ama babana sorarsan geçmişimiz mezbaha. Yalnız pislik, yalnız yabanilik. Ve sessizlik. Kimseler glk dememiş. Peki, kimin geçmişi güzel? Şimdi kapılanmak istediğin insanların ecdadı pek mi cici çocuk? Din uğruna sefer açan Haçlılar şu İstanbul'da kendi dindaşlarına neler yapmışlar, duymadın mı? İnsanları diri diri yakan engizisyon esnafi... İliğini emdikleri memleketlerde direnenleri top ăgzına bağlayıp parçalayan sömürgeciler... Bosna canavarları... Beğeniyor musun bunları? Neden hep bizde eksi, o yanda artı görmektesin " (s. 19).
\end{abstract}

Oğlunu tüm çabalarına rağmen ikna edemeyen Zehra düzene karşı başkaldırı ve mücadele vurgusu yapmaktan vazgeçmez. Bu uğurda birçok önemli ismin hayatlarını çileler içinde hapishanelerde tükettiğini yahut düzene kafa tuttuğu için öldürüldüğünü dile getirir. Nesimi, Köroğlu, Nazım Hikmet ve Uğur Mumcu onun kahramanlarıdır. Bu noktada yazar "devrimci romantizm" çizgisinde önemli bir özelliğe daha dikkat çeker. Mutlu bir gelecek için çekilen cefa ve yaşanan zorluklar gereklidir. Çile ve devrim mücadelesi çerçevesinde yazar yine Nazım Hikmet'in mücadelesini hatırlatır.

Eserin sonlarında devrimci romantizm esasına bağlı bir özellik daha dikkat çeker. Zehra intiharın eşiğine gelmişken babasının hayaliyle özlem giderir ve onun tavsiyelerini dinleyerek kırılgan yapısından kurtulur ve geleceğe yönelik iyimser bir bakış açısı sergilemeye başlar. Toplumcu gerçekçi eserlerde sıkça kullanılan geleceğe iyimser bakma ögesi bu eserde de devrimci romantizme bağlı olarak karşımıza çıkar. Zehra babasına seslenir ve her şeyin daha güzel olacağına inandığını dile getirir.

"ZEHRA - .... Babacığım, senin de için rahat olsun. Vasiyetin yerine gelecek, her şey senin biraktığından iyiye gidecek. Onu başarmadan ölürsem bana da Zehra demesinler" (s. 74).

\title{
Yan Tutarlık Ya da Partizanlık
}

Ahmet Oktay’a göre partizanlı Stalinizmin yıkılmasından sonra ortaya çıkan farklı demokratik havanın etkisiyle oluşmuş ve yan tutarlık kavramıyla karşılanmıştır. Bu kavrama göre yazar emekçilerin taraf tarafını tutmalı, onların hakkını savunmalı ve eğitimi için çalışmalıdır (Oktay, 1986: 209). Karl Marks'ın öncüsü olduğu sosyalist gerçekçiliğin temelinde siyasi bir ideoloji vardır ve bu ideolojinin siyasetteki temsilcisi Komünist Parti'dir. Bu kuramı benimseyen sanatçılar da eserlerinde kuramın felsefesini anlatarak sosyalist- komünist odaklı kahramanlar yaratır. Refik Erduran da bu çizgide Nazım Hikmet etkisiyle benimsediği "partizanlık ya da yan tutarlık" ögesini oyunlarında sıkça kullanır.

Oyunda s1k s1k vurgulanan "mücadele", "kavga" ve "devrim" yan tutarlık ögesine bağlı olarak ortaya çıkar. Sistemin değişmesini isteyen yazar komünizm odaklı düşüncelerini paylaşmaktan kaçınmaz. Aksine eserde sık sık Enternasyonal Marşı'nı arka fon olarak kullanır ve bu sırada başkahraman Zehra aracılığıyla devrim propagandası yapar.

Eserde partizanlık ögesine bağlı olarak ilk örnek henüz kitabın başında karşımıza çıkar. Adı geçmeyen partinin başa geçebilmesi ve her şeyin bu sayede düzeleceği inancına sahip olan bir gençten bahsedilir. Zehra'nın kızı Ece'nin nişanlısı olan bu genç eserde de Nişanlı adıyla anılır. 
Oyun boyunca sadece bir diyalogla karşımıza çıkan genç bağlı olduğu parti adına devrim propagandası yaptığı için öldürülür.

"NiŞANLI-Bayllyorum sana. Ama...

ECE - Devrime daha çok bayllyyorsun?

NiŞANLI - Birbirinden ayrı şeyler değil ki. Önce toplum doğuracak. Sonra çocuklarımız doğacak, insanca bir dünyada” (s. 6).

Toplumcu gerçekçi anlayışta yansıtılan gerçeklik, o sırada mevcut olan durumun yanı sıra gelecekte alacağı şekli de kapsar. Yazar bir başka deyişle ideal olanı sunar ve yeri geldiğinde bu durumu açıkça över (Moran, 2004: 112). Refik Erduran da eserinde ideal yapıyı sunar ve ileride yapılacak hayali bir devrimle bu ideal yapıya ulaşılabileceğini dile getirir. Bunu yaparken de ideal yapıyı savunacak bir aydın tipi yaratır. Olayların merkezinde yer alan Zehra eser boyunca sömürüye, eşitsizliğe karşı çıkarak ezilenlerin yanında olan muhalif bir insan modeli olarak dikkat çeker. Bir partinin temsilcisi olmasa da savunduğu ideolojiyle tarafını belli eder. Nazım Hikmet ve Uğur Mumcu gibi isimlerden ilham alan Zehra, mücadelenin karşı tarafın saltanatı bitene kadar devam edeceğini vurgular. Bu bağlamda ideal yapıya ulaşmak için devrim propagandası yapması, iktidarın yıkılmasını isteyen muhalif kişiliği yanlı bakış açısının bir sonucudur. Ayrıca muhalifliğinin daimi olduğunu söylemesi de ideolojisine ve savunduğu partiye bağl1lığından kaynaklanmaktadır.

"ZEHRA - Dava hayal üstüne değil. Senin gibilerin namussuzluğu üstüne. Kavga bitmedi, çünkü sizin saltanatınız bitmedi” (s. 43).

\section{Tarihselcilik}

Berna Moran'a göre Toplumcu gerçekçi anlayışı yansıtan eserlerde, olayları meydana getiren kişiler belli zaman ve mekâna entegre edilir. Böylece toplum, tarihsel bir döneme dâhil olur. Yazarın görevi ise eserindeki kişi, olay bağlantısını tarihle ilişkilendirmek, toplumun belli dönemlerindeki tarihsel olguları tespit etmek ve toplumun iç dinamiklerini dikkate alarak dönem içerisindeki tarihî durumu anlamaktır (Moran, 2004: 55).

Refik Erduran oyun boyunca yer yer tarihselcilik ögesinden yararlanır. Yarattığ1 başkahraman Zehra, sömürgeci düzene ve Batı'ya karşı kendi değerlerini savunurken tarihten sık sık faydalanır. Batı hayranlığı ile ülkesinin geçmişini aşağılayan oğluna ve kocasına tarihi hatırlatmalarla cevap vermesi tarihselcilik ögesiyle ilişkilidir. Oğlu Efe'nin Türk toplumunu koyuna benzetmesi ve sömürge düzeninin bir parçası olduğunu dile getirmesi annesi Zehra'ya IV. Murat döneminde Nefi'nin padişahın devlet adamlarını yerdiği için idam edilişini hatırlatır. “.... Yaşslllkk döneminde Padişah IV. Murat. Osmanlı'nın en şakaya gelmez hükümdarı. Nefi onun paşalarını da perişan ediyor kalemiyle. Ne uyarı dinliyor, ne tehdit" (s. 21). Yazar bu örneği verirken Vezir Gürcü Mehmet Paşa, Şeyhülislam ve Padişah IV. Murat'ın Nefi ile diyaloglarına da yer verir. Bu noktada tarihsellik ögesi gerçekçiliğin bir destekleyicisidir. Yaratılan diyaloglarla okuyucu hem IV. Murat Dönemi hakkında bilgi sahibi olur hem de tarih-gerçeklik ilişkisini kurar.

\section{"NEFI - Buyur Padişah'ım! \\ 4. SES - Seni severim. Ama kirdı̆ğn ceviz bini aşt. En muteber kullarım senin kelleni isterler. Bir daha kimseye taş atmayacağına yemin et, canının bağışlayayım"(s. 22).}

Eserde olayların meydana geldiği zamanla ilgili net bir bilgi olmamasına rağmen olay ve kişi ilişkisi içinde tarihselcilik ögesi kullanılarak zaman dilimiyle ilgili öngörü sağlanabilmektedir. Ece'nin nişanlısının devrim propagandası yaparken ölmesi, Zehra'nın Nazım Hikmet'in devrim mücadelesinde hapiste geçirdiği yılları ardından da Uğur Mumcu'nun suikast sonucu ölümünü hatırlatması olaylar zinciri bakımından geniş bir zaman dilimi aralığının dikkate alındığını göstermektedir. Bu zaman aralığı ise 1950-2000 yılları arasını kapsamaktadır. 


\section{Ekonomik ve Sınıfsal Çatışmalar}

Toplumcu gerçekçi anlayışla oluşturulan eserlerin bağlı olduğu esaslardan biri de çatışma ögesidir ve kuramda çatışma ögesi genel itibariyle ekonomi odaklı olarak işlenir. "Toplumcu gerçekçi eserlerde toplumu meydana getiren ekonomik temelli diyalektik yapı, diyalektik yapıyı meydana getiren sınıflar ve bu sinıfların çatışmaları, kitle hareketleri, kapitalizmin eleştirisi, kapitalist sistemin sömürücülüğ̈̈ çok sık karşımıza çıkar” (Demir, 2008: 79). Marksizm temelli bu bu bakış açısına göre ortaya çıkan sınıf farklılığı ekonomik eşitsizliğin bir sonucudur.

Refik Erduran eserinde ekonomik temelli diyalektik yapıyı oluştururken ezen-ezilen ilişkisinden faydalanır. Bunun yanı sıra Doğu-Batı çatışması çerçevesinde yarattığı karşıt düşünceli kahramanlar üzerinden sömürge düzenini ve kapitalizmi eleştirir. Bu bağlamda yaratılan ekonomik temelli çatışma ile ezilenlerin hakları hatırlatılır ve ekonomik eşitlik vurgusu yapılır.

Oyunun başlarında başkahraman Zehra kendi ailesi ve eşi Nuh'un ailesi hakkında bilgi verir. Bu sırada kendi ailesini "köylü", Nuh'un ailesini ise "zarif" kelimesiyle karşılar. Yazar bu noktada ekonomik temelli bir "köylü-kentli" çatışması oluşturur.

"ZEHRA - .... Nuh'un anası babasl "zarif" insanlardı. Eski İstanbullu, Osmanlı uzantisl, bir hayli de Fransız kültürlü, pasaporta "paspor" derlerdi. Benim köylü anamsa ölene kadar k'ları g gibi söyledi. Glz aşağı, gız yukarı. Nuh belli etmemeye çalışırdı ama utanırdı kaynanasından. "İnsan içine" çıkacağım diye ödü kopardı" (s. 13).

Olayların merkezinde yer alan Zehra kocasının ve oğlunun Batı hayranlığı ile Avrupa'ya gitmesini sindiremez. Çünkü oğlu ve kocası Doğu'yu, Osmanlıyı ve Türklerin tarihini her firsatta aşağılar. Zehra ise bu noktada özellikle oğluna sitemde bulunarak Batı'nın tarihinden örneklerle kapitalist ve sömürgeci tutumu eleştirir. “.... Iliğgini emdikleri memleketlerde direnenleri top ă̆zına bağlayıp parçalayan sömürgeciler... Bosna canavarları... Beğeniyor musun bunları? Neden hep bizde eksi, o yanda artı görmektesin“" (s. 19).

Nuh'un Batı'da kapitalist sisteme ayak uydurması onun insanlara bakışında bir sınıf ayrımcılığı politikası gütmesine sebep olur. Nuh köylüler için "yarı hayvan" ibaresini kullanır.

"NUH - Saçmalama. Hakllsıln onlardan kopuk olmakta. Köylü dediğin yarı hayvandır.

Hayvan gibi doğar, hayvan gibi ölür. Arada çile doldurur ama onun da farkında değildir... Yalan mı?" (s. 27).

Ekonomik temelli bir başka çatışma da eserde yer alan Kezban karakteri üzerinden yapılır. Kezban temizlik işçisi bir köylü kızıdır ve sevdiği adam onu hamile bırakıp Almanya'ya yerleşir. Çocuğunu doğurduktan sonra kötü yola düşen Kezban hayat kadını olur. Ezen-ezilen ilişkisi yine ekonomik çatışmayla oluşan sınıf farklılığına bağlanır.

"ZEHRA - Beni bırak. Ama Kezban ü̧ türlü eziliyor. Önce, senin gibilerin taşra saydıkları bir memlekette doğduğu için. Sonra, o memleketin alt katında yetiştiği için. En kötüsü de, kadın olduğu için. Kezban'ı hem Avrupa ezdi, hem İstanbul ezdi, hem de kocası ezdi" (s. 39).

Eser boyunca benzer örneklerle karşımıza çıkan ekonomik çatışma unsuru eserin sonlarında Zehra'nın hastane odasından inşaatta çalışan işçileri izlerken yaptığ 1 yorumla son bulur. Zehra arka fonda tekrar duyulan Enternasyonal Marşı eşliğinde işçilerin yaptığı gökdelenin ileride bir "plaza" olacağını ve karınca gibi çalışan bu emekçilerin sınıf farkı ve ekonomik zayıflıkları sebebiyle o plazaya adım dahi atamayacaklarını hatırlatır. Bu noktada bir yandan işçiler için sosyalizm odaklı bir mesaj veren yazar diğer yandan ekonomik çatışma sonucunda ezen-ezilen ilişkisini yaratan Kapitalizmi eleştirir.

"Şu yapıda çalı̧̧anlara bak. Karıncaya benzetiyordum bunları. Hiç düşünmeden bir şeyler taşlyıp duruyorlar diye. Diktikleri gökdelene özenti bir yabancı adı takalacak. 
Mă̆azalarında özentili kişiler özentili alışverişler yapacak. Bizimkiler adım bile atamayacaklar içine. Ama belki yanılıyorum. Belki karınca gibi yaşayanlar da hafiften hafife düşünmeye başlamışlardır artık. ....” (s. 73).

\section{Sonuç}

Refik Erduran, toplumcu gerçekçi anlayışı temsil eden bir sanatçıdır ve bu anlayışın temelini oluşturan Marksist, sosyalist felsefeye bağlı unsurları eserlerinde sık sık kullanır. Devrim, ezenezilen ilişkisi, ekonomik çatışmalar, tez-antitez, sınıfsal farklılık ve geleceğe yönelik iyimserlik bu bağlamda en çok kullandığı ögelerdir.

Refik Erduran bu eserinde toplumcu gerçekçi anlayışa bağlı eserlerin temelini oluşturan "özün ve gerçeğin önceliği” ile "yan tutarlık ya da partizanlık” ilkelerine bağlı kalmıştır. Eserde içeriği yani vermek istediği sosyalizm temelli mesajı ön plana çıkaran yazar bir taraftan da devrim hayalini gerçekleştirme yolunda işçi ve emekçinin hakkını savunarak tarafını belli eder. Eserinde bu ilkeleri yansıtan yazar bir diğer önemli ilke sayılan "devrimci romantizm ve doğal uzantısı olumlu tip" i sınırlı şekilde ele alır. Gerçeklerle hayali bir devrimi yan yana getirmesi ve her şeye rağmen geleceğe güvenmesi devrimci romantizmin bir parçası olarak ortaya çıksa da yarattı̆̆ "olumlu tip" ideal kurtarıcı perspektifine göre sınırlı kalır. Olayların merkezinde yer alan bu kahraman düşünsel boyutta beklentiyi karşılasa da eylemsel boyutta "kurtarıcı" değildir. Bunun yanı sıra yazar, toplumcu gerçekçi anlayışın temel ilkelerini destekleyen "tarihselcilik", "ekonomik ve sınıfsal çatışma" gibi ögelere de eserinde yer verir. Tarih bilincine sahip, aydın bir kahraman yaratan yazar dönemlerle ilişkili olarak tarih-gerçeklik ilişkisini kurar. "Ekonomik ve sınıfsal çatışma" noktasında ise köylükentli, ezen-ezilen iliş̧kilerini yansıtarak oluşan ekonomi odaklı eşitsizliği ve yine bu bağlamda tüm bu çatışmaların sebebi olarak gördüğü Kapitalizmi eleştirir.

\section{Kaynakça}

Akpınar, S. (2014). Toplum, Sanat ve İdeoloji Üçgeninde Toplumcu Gerçekçiliğin Edebiyat ve Siyaset İlişkisine Yaklaşımı, Uluslararası Sosyal Araştırmalar Dergisi, 7(30), 7-26.

Aydoğdu, Y. (2017), Cumhuriyet Dönemi Türk Edebiyatında Toplumcu Gerçekçi Şiirin Serüveni, Bingöl Üniversitesi Sosyal Bilimler Enstitüsü Dergisi, Yı1: 7, 7(14), 267-282.

Çetişli, İ. (2004). Batı Edebiyatında Edebî Akımlar, Akçağ Yayınları.

Demir, A. (2008).Toplumcu Gerçekçi Objektiften Yansıyan Bir Anadolu Fotoğrafi: Bacayı İndir, Bacayı Kaldır, Modern Türklük Araştırmaları Dergisi, 5(1), 65-80.

Erduran, R. (1979). Cengiz Han'ın Bisikleti, Devlet Tiyatroları Genel Müdürlüğü.

Erduran, R. (1993). Tamirci, Gerçek Sanat Yayınları.

Erduran, R. (1998). Yemenimin Uçları, Kültür Bakanlığı.

Erduran, R. (2005). İblisler, Azizler, Kadınlar, Dünya Kitapları Yayınevi.

Erduran, R. (2011). Tiyatro Açılımı Söyleyişi, İstanbul Kültür Üniversitesi Yayınevi.

Gülmen N. (2016). Nazım Hikmet'in Yusuf ile Menofis ve Ferhad ile Şirin Oyunlarında Toplumcu Gerçekçilik Bağlamında Yeniden Yazma Pratiği, Eskişehir Osmangazi Üniversitesi Sosyal Bilimler Enstitüsü (Yüksek Lisans Tezi).

Gürsel, N. (2001). Doğumunun Yüzüncü Yılında Dünya Şairi Nâzım Hikmet, Can Yayınları.

Hikmet N. (2012). Sanat ve Edebiyat Üstüne, (Haz.: Aziz Çalışlar), Evrensel Basım Yayın. 
Irmak, E. (2009). Kayıp Destanın İzinde: Kuvâyi Milliye ve Memleketimden İnsan Manzaraları'nda Milliyetçilik, Propaganda ve İdeoloji, İletişim Yayınları.

Kahraman, H. B. (2004). Türk Şiiri, Modernizm, Şiir, Kapı Yayınları.

Moran, B. (2004). Edebiyat Kuramları ve Eleştiri, İletişim Yayınları.

Oktay, A. (1986). Toplumcu Gerçekçiliğin Kaynakları, BFS Bilim Felsefe Sanat Yayınları.

Pospelov, G. N. (1985). Edebiyat Bilimi Cilt II, (Çev.: Y. Onay), Bilim Sanat Yayınları.

Ran, N. H. (2008). "Kübalı Sanatçılarla Söyleşi”, (Çev.: A. N. Akbulut), Varlık Dergisi, Sayı: 939, 4-6.

Soğukömeroğulları, M. (2010). Ahmet Ümit'in Kar Romanında Toplumcu Gerçekçilik, Turkish Studies, 5(1), 1311-1327.

Tunal1, İsmail (1976). Marksist Estetik, Altın Kitaplar Yayınevi. 